\title{
Optimalisasi Pertumbuhan dan Daya Hasil Nenas dengan Menggunakan Berbagai Mulsa di Lahan Pasca Tambang Timah
}

\author{
(Optimization of Growth and Yield Potential of Pineapple by Application of Various \\ Mulch in Post-Tin Mining Land)
}

Tri Lestari ${ }^{*}$, Rion Apriyadi ${ }^{1}$, Eries Dyah Mustikarini ${ }^{1}$, Alif Satria ${ }^{1}$, Niken Dwiyulivia Yasmin ${ }^{1}$

Diterima 8 Oktober 2019/Disetujui 25 Juli 2020

\begin{abstract}
The cultivation of pineapple in post-tin mining land requires a special treatment to maintain soil microclimates. One of treatment that can be used is the application of mulch. The research aims to know the best type of mulch for pineapple cultivation in post-tin mining land. This research had been conducted from January 2018 to May 2019, located on post-tin mining land, Dwi Makmur Village, Merawang, Bangka, Laboratorium of Agrotechnology, University of Bangka Belitung, and Saraswanti Indo Genetech, Bogor. The research used a randomized block design with single factor treatment, namely mulch type. The type of mulch consisted of without mulch (MO), Arachis pintoi (M1), coconut fiber mulch (M2), and reed mulch (M3). The result of this research showed that types of mulch did not give any significan effect on vegetative and generative pineapple growth. The application of mulch did not show a significant effect on the plant microclimate (air temperature and soil humidity). Several parameters on fruit (number of pods, fruit weight with and without crown) tended to be higher in the treatment without mulch. Application of Arachis pintoi showed the highest vitamin $C$ content $(9.83 \mathrm{mg})$ in fruit. Pineapple planted on post-tin mining land did not contain $\mathrm{Pb}, \mathrm{Cu}, \mathrm{Sn}$ is safe for human consumption.
\end{abstract}

Keywords: Arachis pintoi, coconut fiber, fruit quality, post-mining lands

\begin{abstract}
ABSTRAK
Budidaya nenas di lahan pasca tambang timah memerlukan perlakuan khusus untuk menjaga mikroklimat tanah. Salah satu perlakuan yang dapat digunakan adalah aplikasi mulsa. Tujuan dari penelitian ini adalah untuk mengetahui jenis mulsa yang tepat untuk budidaya tanaman nenas di lahan pasca tambang timah. Penelitian dilakukan bulan Januari 2018 sampai Mei 2019, di Desa Dwi Makmur, Kecamatan Merawang, Bangka, laboratorium Agroteknologi Universitas Bangka Belitung, dan Saraswanti Indo Genetech, Bogor. Penelitian menggunakan rancangan acak kelompok (RAK) dengan perlakuan faktor tunggal yaitu tipe mulsa. Perlakuan mulsa yang terdiri dari tanpa mulsa (M0), Arachis pintoi (M1), mulsa sabut kelapa (M2), mulsa alang-alang (M3). Hasil penelitian menunjukkan penggunaan berbagai jenis mulsa tidak memiliki pengaruh nyata terhadap pertumbuhan vegetatif tanaman nenas. Aplikasi mulsa tidak menunjukkan pengaruh nyata terhadap iklim mikro tanaman (suhu udara dan kelembaban tanah). Beberapa parameter pada buah (jumlah mata buah, bobot buah dengan dan tanpa mahkota) cenderung lebih tinggi pada perlakuan tanpa mulsa. Apikasi mulsa Arachis pintoi menghasilkan kandungan vitamin $\mathrm{C}$ tertinggi $(9.83 \mathrm{mg})$ pada buah nenas. Buah nenas di lahan pasca tambang timah tidak mengandung logam $\mathrm{Pb}, \mathrm{Cu}, \mathrm{Sn}$ sehingga aman dikonsumsi.
\end{abstract}

Kata kunci: Arachis pintoi, sabut kelapa, kualitas buah, lahan pasca tambang

${ }^{1}$ Jurusan Agroteknologi, Fakultas Pertanian, Perikanan, dan Biologi, Universitas Bangka Belitung Kampus Terpadu Desa Balunjak, Kabupaten Bangka 33126, Indonesia

e-mail : trilestari25sm07@gmail.com (*penulis korespondensi) 


\section{PENDAHULUAN}

Nenas (Ananas comosus L.) adalah salah satu komoditas buah unggulan Indonesia karena selain memiliki nilai ekonomis yang tinggi, nenas juga memiliki kandungan gizi yang baik. Buah nenas mengandung zat gizi antara lain kalsium, potasium, klor, kalium, fosfor, sodium, vitamin $\mathrm{C}$, karbohidrat, serat kasar, air, sukrosa, dan bromelin (Hossain et al., 2015). Produksi buah nenas di Indonesia mengalami fluktuasi dari tahun 2015 hingga tahun 2017. Menurut Biro Pusat Statistik (2017), produksi buah nenas tahun 2015 sebesar 1729603 ton, menurun menjadi 1396 153 ton pada tahun 2016, dan meningkat lagi menjadi 1795986 ton pada tahun 2017. Fluktuasi produksi buah nenas disebabkan karena rendahnya jumlah luas panen nenas di Indonesia.

Peningkatan luas panen nenas dapat dilakukan dengan memanfaatkan lahan suboptimal. Nenas merupakan tanaman yang mampu bertahan pada kondisi lahan kering dan kurang menyukai lahan yang tergenang air (Lestari et al., 2011). Nenas dapat menurunkan laju transpirasi karena menutup stomata pada siang hari dan membuka stomata pada malam hari untuk menyerap $\mathrm{CO}_{2}$ (Rahmat et al., 2014). Bangka Belitung merupakan daerah yang memiliki lahan suboptimal yang cukup luas akibat kegiatan penambangan timah. Lahan pasca tambang timah bersifat sangat porous, didominasi tekstur pasir, kapasitas memegang air rendah, $\mathrm{pH}$ tanah sangat masam, kadar C-organik rendah, ketersediaan unsur hara rendah, dan kejenuhan basa rendah (Hamid et al., 2017). Lestari et al. (2011) menambahkan bahwa suhu udara lahan pasca tambang timah mencapai $42-45{ }^{\circ} \mathrm{C}$ dan kelembaban udara $35-40 \%$. Untuk mengatasi masalah pada lahan tersebut, maka budidaya nenas di lahan pasca tambang memerlukan penambahan bahan penutup tanah untuk menjaga mikroklimat agar lebih optimal untuk pertumbuhan tanaman nenas.

Bahan penutup tanah yang dapat digunakan bisa berupa mulsa organik maupun tanaman penutup (cover crop). Jenis penutup tanah yang banyak digunakan untuk kegiatan budidaya tanaman adalah mulsa organik (Basuki et al., 2016). Pemanfaatan mulsa merupakan salah satu upaya untuk menekan pertumbuhan gulma, suhu dan kelembaban tanah, serta menciptakan kondisi yang sesuai bagi tanaman sehingga tanaman dapat tumbuh dan berkembang dengan baik (Damayanti et al., 2013). Beberapa mulsa organik yang dapat digunakan adalah mulsa alang-alang dan mulsa sabut kelapa.

Mulsa alang-alang cenderung memberikan pertumbuhan dan produksi tanaman sawi yang lebih baik karena mampu menekan pertumbuhan gulma dengan mempengaruhi cahaya sampai ke permukaan tanah sehingga kecambah gulma dan beberapa jenis gulma dewasa mati (Rumakuway et al., 2016). Pemberian mulsa organik alang-alang sebesar $36 \mathrm{~kg}$ per petakan berpengaruh terhadap pertumbuhan dan hasil tanaman tomat (Endang, 2013).

Mulsa sabut kelapa merupakan terobosan baru sebagai media penutup tanah alami yang efektif untuk menekan gulma. Pemberian mulsa sabut kelapa mampu meningkatkan jumlah polong isi dan berat biji per tanaman, serta menurunkan jumlah polong hampa per tanaman pada tanaman kedelai di lahan kering (Endriani dan Barus, 2014). Tanaman penutup (cover crop) yang biasa digunakan adalah jenis legume cover crop (LCC), salah satunya adalah Arachis pintoi. Menurut Chozin et al. (2014), Arachis pintoi sangat baik ditanam sebagai biomulsa pada produksi sayuran dan buah. Silmi et al. (2014) menyatakan bahwa Arachis pintoi dapat membantu meningkatkan pertumbuhan vegetatif tanaman tomat di lahan kering. Berdasarkan uraian diatas, maka penelitian ini perlu dilakukan untuk melihat pengaruh jenis mulsa organik terhadap pertumbuhan dan hasil nenas di lahan pasca tambang timah. Analisa kandungan buah nenas diuji laboratorium dilakukan untuk mengetahui kandungan logam berat yang aman dikonsumsi.

\section{BAHAN DAN METODE}

Penelitian dilaksanakan dalam dua tahapan, yaitu: 1) aplikasi berbagai jenis mulsa organik di lahan pasca tambang timah dan pengamatan pertumbuhan dan perkembangan tanaman, 2) analisa kandungan vitamin $C$ dan mineral logam buah nenas asal perlakuan mulsa organik pascapanen. Penelitian ini dilaksanakan selama 17 bulan yaitu pada bulan Januari 2018 sampai dengan Mei 2019 di lahan 
pasca penambangan timah Desa Dwi Makmur, Kecamatan Merawang, Bangka, laboratorium Agroteknologi Universitas Bangka Belitung, dan laboratorium Saraswanti Indo Genetech, Bogor.

Bahan yang digunakan dalam penelitian ini adalah bibit tanaman nenas aksesi Bikang, karbit, sabut kelapa, alang-alang, Arachis pintoi, aquades, air, pupuk urea, pupuk TSP, dan pupuk $\mathrm{KCl}$.

Percobaan dilaksanakan dengan menggunakan rancangan acak kelompok dengan satu faktor perlakuan yaitu jenis mulsa. Jenis mulsa yang diuji terdiri dari 4 taraf perlakuan yaitu M0 (tanpa pemberian mulsa), M1 (Arachis pintoi), M2 (mulsa sabut kelapa), M3 (mulsa alang-alang). Setiap perlakuan diulang sebanyak 6 ulangan, sehingga total unit percobaan berjumlah 24 unit percobaan. Mulsa disiapkan seminggu sebelum penanaman. Aplikasi mulsa dilakukan dengan cara menyusun mulsa di atas permukaan bedengan sesuai dengan perlakuan. Mulsa organik yang terdiri dari seresah alang-alang dan sabut kelapa disusun hingga ketebalan 5 $\mathrm{cm}$. Arachis pintoi ditanam di bedengan dengan jarak tanam $20 \mathrm{~cm}$ x $20 \mathrm{~cm}$. Bedengan yang telah diberikan mulsa dibiarkan selama satu minggu setelah itu baru dilakukan penanaman bibit tanaman nenas berukuran tinggi sekitar $20 \mathrm{~cm}$ dan jumlah daunnya 10 helai. Pengukuran pertambahan tinggi tanaman, jumlah daun, lebar tajuk tanaman, panjang akar, lebar sebaran akar, suhu tanah dan kelembaban tanah diukur pada 16 MST. Tanaman nenas dari perlakuan berbagai jenis mulsa dipanen apabila buah telah memenuhi kriteria panen. Buah nenas yang telah dipanen dihitung jumlah daun mahkota, jumlah mata buah, bobot buah dengan mahkota, bobot buah tanpa mahkota, dan diameter buah.

Untuk analisis kandungan buah nanas, dari setiap unit percobaan diambil 1 buah nenas sebagai sampel uji, sehingga total sampel diuji sebanyak 24 sampel buah nenas. Kandungan buah nenas diuji setelah buah nenas dihitung jumlah daun mahkota, jumlah mata buah, bobot buah dengan mahkota, bobot buah tanpa mahkota, dan diameter buah. Uji total padatan terlarut dilakukan dengan mengambil ekstrak buah nenas kemudian diteteskan di alat refraktometer. Analisis kandungan vitamin $\mathrm{C}$ dan kandungan logam berat timbal $(\mathrm{Pb})$, tembaga $(\mathrm{Cu})$, timah $(\mathrm{Sn})$ buah nenas diuji di laboratorium (SIG) Saraswanti Indo Genetech, Bogor.

Metode yang digunakan untuk menganalisis vitamin $\mathrm{C}$ pada buah nenas adalah metode Kromatografi Cair Kinerja Tinggi (KCKT). Cara kerja uji vitamin C dengan metode KCKT pada buah nenas adalah buah nenas di kupas dari kulitnya kemudian daging buah nenas dihaluskan menggunakan blender. Daging buah nanas yang telah halus disaring sehingga didapatkan ekstrak cair,kemudian ekstrak cair $100 \mathrm{ml}$ dimasukan ke dalam 6 erlemeyer dan masing- masing elenmeyer ditambahkan $15 \mathrm{ml}$ kloroform. Erlenmeyer kemudian ditutup menggunakan almunium foil dan bagian atasnya diberi lubang menggunakan jarum. Erlenmayer tersebut lalu dimasukan ke lemari pendingin selama 24 jam sehingga diperoleh endapan berupa kristal. Kristal yang diperoleh kemudian dipisahkan menggunakan penyaring. Kristal sebanyak $50 \mathrm{mg}$ dimasukan kedalam labu ukur $100 \mathrm{~mL}$ dan kemudian ditambahkan metaphosphoric acid (MPA) $0.56 \% \mathrm{w} / \mathrm{v}$ hingga tanda batas lalu disaring menggunakan kertas saring di dalam labu ukur $100 \mathrm{~mL}$ dan ditambahkan metaphosphoric acid (MPA) $0.56 \% \mathrm{w} / \mathrm{v}$ hingga tanda batas. Kemudian larutan dipipet $2 \mathrm{ml}$ dan dimasukan ke labu ukur $10 \mathrm{ml}$ dan ditambah metaphosphoric acid (MPA) 0,56\% w/v hingga tanda batas. Larutan kristal disaring mengunakan penyaring $0.45 \mu \mathrm{m}$ kemudian diinjeksi ke KCKT dengan fase gerak asam asetat $0.1 \%$ dan metanol (95:5) (Jubahar et al., 2015).

Uji logam berat $(\mathrm{Pb}, \mathrm{Cu}$, dan $\mathrm{Sn})$ dilakukan dengan menggunakan metode Inductively Coupled Plasma Optical Emission Spectrometry (ICP OES). ICP OES adalah alat yang digunakan untuk menentukan kandungan logam dalam berbagai sampel (Ghosh et al., 2013).

\section{HASIL DAN PEMBAHASAN}

Pengaruh Aplikasi Berbagai Jenis Mulsa terhadap Pertumbuhan Dan Daya Hasil Tanaman Nenas di Lahan Pasca Tambang Timah

Aplikasi berbagai mulsa memberikan pengaruh yang tidak nyata terhadap peubah pertumbuhan dan daya hasil nenas kecuali 
pada peubah panjang buah. Pada Tabel 1 menunjukkan hasil rata-rata peubah pengamatan diakhir penelitian. Rata-rata pertambahan tinggi tanaman pada 16 MST adalah $54.5 \mathrm{~cm}$. Rata-rata pertambahan lebar tajuk tanaman pada 16 MST adalah $54.7 \mathrm{~cm}$. Rata-rata pertambahan jumlah daun pada 16 MST adalah 16 helai. Rata-rata panjang akar pada 16 MST adalah $53 \mathrm{~cm}$ dan rata-rata lebar sebaran akar adalah $38.8 \mathrm{~cm}$. Arachis pintoi dapat membantu memperbaiki status hara pada tanah dengan kemampuannya menambat nitrogen di dalam tanah. Mulsa Arachis pintoi dapat membantu memperbaiki status hara pada tanah dengan kemampuannya menambat nitrogen di dalam tanah (Munawir dan Chozin, 2015). Namun dalam penelitian ini, pengaruh posited Arachis pintoi belum terlihat diduga karena pertumbuhan Arachis pintoi yang belum maksimal.

Meskipun mulsa sabut kelapa dapat menurunkan suhu tanah dan meningkatkan kelembaban tanah seperti terlihat pada Tabel 2, namun hal tersebut belum berpengaruh signifikan terhadap pertumbuhan tanaman.

Tabel 2 menunjukkan bahwa suhu tanah akhir setelah aplikasi mulsa sabut kelapa menjadi $27.4{ }^{\circ} \mathrm{C}$ menurun $4{ }^{\circ} \mathrm{C}$ dari suhu awal sebelum aplikasi mulsa dan kelembaban meningkat $2.5 \%$ menjadi $19.8 \%$ dari kelembaban awal sebelum aplikasi mulsa. Mulsa sabut kelapa memiliki kemampuan untuk menyerap air sehingga dapat menjaga suhu dan kelembapan tanah. Kondisi tersebut berdampak pada pertumbuhan jumlah daun. Edriani dan Barus (2014) menyatakan bahwa pemberian mulsa sabut kelapa juga berguna untuk meningkatkan suhu dan kelembapan tanah sehingga mikroba tanah cepat berkembang baik.

Perlakuan jenis mulsa tidak berpengaruh nyata terhadap beberapa karakter pada buah. Gambar 1a menunjukkan jumlah daun mahkota pada perlakuan mulsa yang tidak berbeda nyata satu sama lainnya. Karakter buah lainnya meliputi jumlah mata buah (Gambar 1b), diameter buah (Gambar 1c), bobot buah tanpa mahkota (Gambar 1d), diameter buah (Gambar 1d) dan padatan total terlarut (PTT) meskipun terlihat lebih tinggi daripada kontrol dan perlakuan mulsa sabut kelapa, namun secara statistik tidak berbeda nyata satu sama lainnya. Hal ini kemungkinan disebabkan kondisi iklim mikro yang ditimbulkan oleh perlakuan antar ulangan sehingga menimbulkan keragaman yang tinggi dalam perlakuan.

Tabel 1. Rata-rata nilai pengaruh berbagai jenis mulsa terhadap pertambahan tinggi tanaman, pertambahan tajuk tanaman, pertambahan jumlah daun, panjang akar, dan lebar akar pada 16 MST

\begin{tabular}{lccccc}
\hline \multicolumn{1}{c}{ Perlakuan } & $\begin{array}{c}\text { Pertambahan } \\
\text { tinggi tanaman } \\
(\mathrm{cm})\end{array}$ & $\begin{array}{c}\text { Pertambahan } \\
\text { tajuk tanaman } \\
(\mathrm{cm})\end{array}$ & $\begin{array}{c}\text { Pertambahan } \\
\text { jumlah daun } \\
\text { (helai) }\end{array}$ & $\begin{array}{c}\text { Panjang } \\
\text { akar }(\mathrm{cm})\end{array}$ & $\begin{array}{c}\text { Lebar } \\
\text { perakaran } \\
(\mathrm{cm})\end{array}$ \\
\hline $\begin{array}{l}\text { Tanpa mulsa } \\
\begin{array}{l}\text { Kontrol) } \\
\text { Arachis pintoi }\end{array}\end{array}$ & 54.4 & 54.4 & 15.1 & 45 & 31.0 \\
$\begin{array}{l}\text { Mulsa sabut } \\
\text { kelapa }\end{array}$ & 57.9 & 57.5 & 15.6 & 53.5 & 49.5 \\
$\begin{array}{l}\text { Mulsa alang- } \\
\text { alang }\end{array}$ & 53.6 & 53.6 & 16.5 & 61.5 & 55.5 \\
Rata-rata & 52.2 & 53.2 & 16.3 & 52.1 & 19.1 \\
\hline
\end{tabular}

Tabel 2. Rata-rata suhu dan kelembaban pertumbuhan vegetatif tanaman nenas mengunakan berbagai jenis mulsa di lahan pasca tambang timah

\begin{tabular}{lcccc}
\hline \multicolumn{1}{c}{ Perlakuan } & $\begin{array}{c}\text { Suhu awal } \\
\left({ }^{\circ} \mathrm{C}\right)\end{array}$ & $\begin{array}{c}\text { Suhu akhir } \\
\left({ }^{\circ} \mathrm{C}\right)\end{array}$ & $\begin{array}{c}\text { Kelembaban } \\
\text { awal }(\%)\end{array}$ & $\begin{array}{c}\text { Kelembaban } \\
\text { akhir }(\%)\end{array}$ \\
\hline Tanpa mulsa (Kontrol) & 31.7 & 30.4 & 16.2 & 16.6 \\
Arachis pintoi & 30.3 & 29.4 & 17 & 17.8 \\
Mulsa sabut kelapa & 31.4 & 27.4 & 17.3 & 19.8 \\
Mulsa alang-alang & 31.2 & 28.3 & 17.5 & 18.3 \\
\hline
\end{tabular}




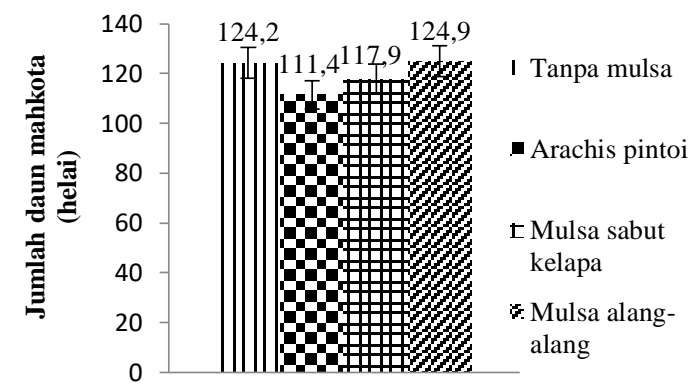

(a)

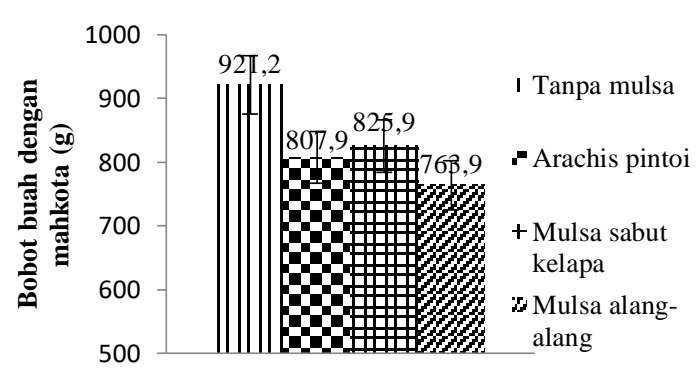

(c)

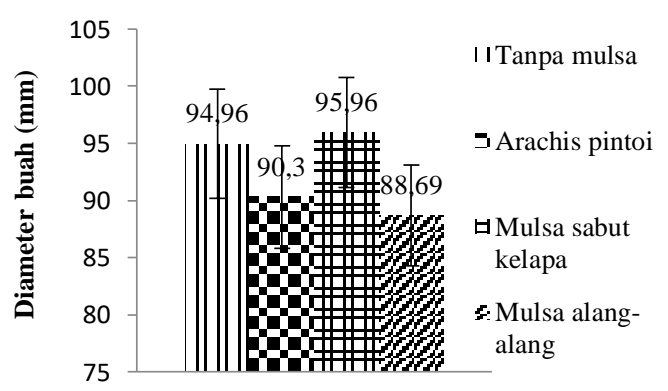

(e)

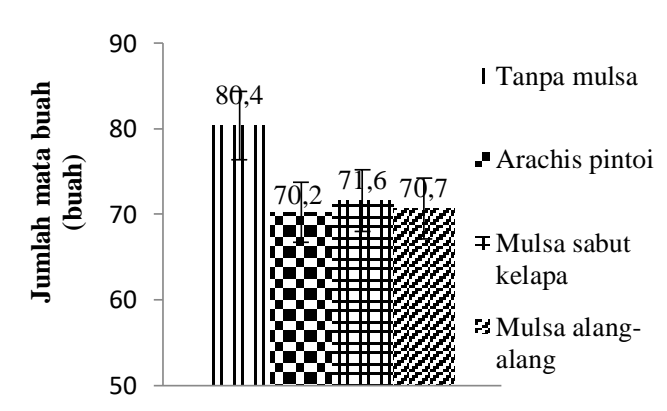

(b)

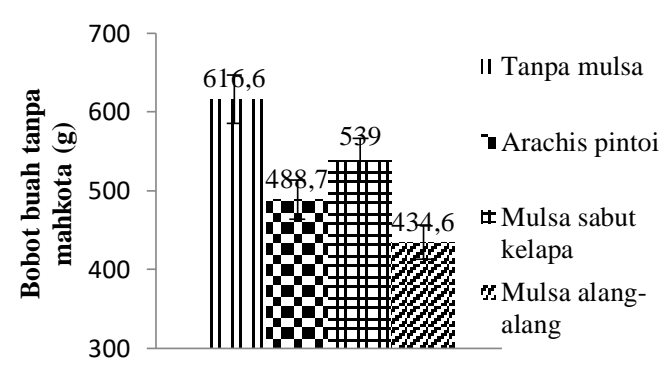

(d)

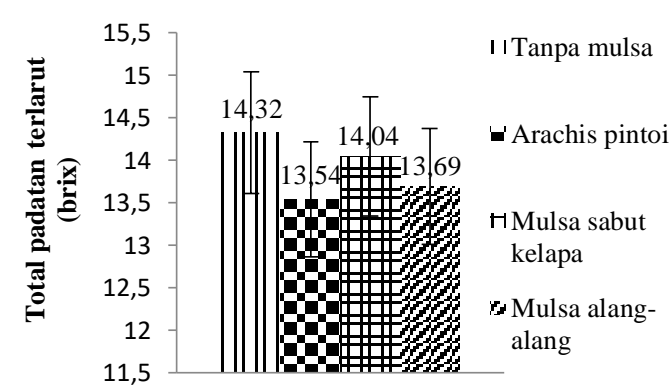

(f)

Gambar 1. (a) Rerata jumlah daun mahkota, (b) jumlah mata buah, (c) bobot buah tanpa mahkota, (d) bobot buah dengan mahkota, (e) diameter buah, dan (f) total padatan terlarut dengan perlakuan berbagai jenis mulsa

Mulsa alang-alang dan sabut kelapa merupakan mulsa organik yang dapat terdekomposisi sehingga dapat menambah hara yang dapat digunakan tanaman. Mulsa organik yang diberikan pada lahan pertanaman lambat laun akan terdekomposisi (terjadi mineralisasi) yaitu perubahan bentuk organik menjadi anorganik sehingga unsur hara yang dilepaskan akan menjadi tersedia untuk tanaman (Antari et al., 2014). Menurut Puspitasari et al. (2013) unsur hara yang tersedia akibat penambahan mulsa alang-alang antara lain unsur nitrogen $(\mathrm{N}) 1.32 \%$, fosfor (P) $0.90 \%$, dan kalium (K) $0.84 \%$. Menurut
Haryadi et al. (2015), unsur $\mathrm{N}$ dan $\mathrm{P}$ berpengaruh dalam proses pembentukan daun. Kedua unsur hara ini berperan dalam pembentukan sel - sel baru dan komponen utama penyusun senyawa organik dalam tanaman yang mempengaruhi pertumbuhan tanaman, khususnya peningkatan jumlah daun. Unsur K berperan dalam mengatur pergerakan stomata, sehingga dapat membantu meningkatkan pertumbuhan jumlah daun tanaman. Meskipun demikian, dalam penelitian ini analisis hara tanah tidak dilakukan, namun dari hasil pertumbuhan tanaman yang tidak berbeda nyata diduga 
mulsa alang-alang atau sabut kelapa yang diberikan tidak mempengaruhi kandungan hara tanah.

Perlakuan tanpa mulsa menunjukkan hasil rerata bobot buah dengan mahkota, bobot buah tanpa mahkota, dan jumlah mata buah dibandingkan perlakuan lainnya tidak berbeda nyata. Hal ini diduga karena tanaman nenas merupakan tanaman CAM. Tanaman CAM dapat tumbuh optimal pada lahan dengan kondisi suhu dan intensitas cahaya yang tinggi. Menurut Rahmat et al. (2014) nenas secara alami merupakan tanaman yang tahan terhadap kekeringan (xerofit) karena nenas termasuk jenis tanaman crassulacean acid metabolism (CAM), yaitu tanaman yang membuka stomata pada malam hari untuk menyerap $\mathrm{CO} 2$ dan menutup stomata pada siang hari. Hal ini akan mengurangi lajunya transpirasi. Nenas memerlukan sinar matahari yang cukup untuk pertumbuhan.

\section{Analisa Kandungan Buah Nenas yang Ditanam di Lahan Pasca Tambang Timah}

Peubah total padatan terlarut perlakuan tanpa mulsa memiliki nilai tertinggi yaitu $14.32{ }^{\circ}$ brix sedangkan perlakuan Arachis pintoi menunjukkan nilai terendah yaitu 13.54 obrix. Peubah vitamin $\mathrm{C}$ pada perlakuan Arachis pintoi menunjukkan nilai tertinggi yaitu $9.83 \mathrm{mg}$ sedangkan perlakuan mulsa alang-alang menunjukkan nilai terendah yaitu $3.86 \mathrm{mg}$. Hasil analisis menunjukkan bahwa buah nenas yang ditanam di lahan pasca tambang timah tidak mengandung logam berat $\mathrm{Pb}, \mathrm{Cu}$, dan $\mathrm{Sn}$ pada semua perlakuan (Tabel 4).

Tabel 4. Analisis kandungan total padatan terlarut, vitamin $\mathrm{C}, \mathrm{Pb}, \mathrm{Sn}$, dan $\mathrm{Cu}$ pada buah nenas

\begin{tabular}{|c|c|c|c|c|c|}
\hline Perlakuan & $\begin{array}{c}\text { Total Padatan } \\
\text { Terlarut ( }{ }^{\circ} \text { brix) }\end{array}$ & $\begin{array}{c}\text { Vitamin C } \\
(\mathrm{mg})\end{array}$ & $\begin{array}{c}\mathrm{Pb} \\
(\mathrm{ppm})\end{array}$ & $\begin{array}{c}\mathrm{Sn} \\
(\mathrm{ppm})\end{array}$ & $\begin{array}{c}\mathrm{Cu} \\
(\mathrm{ppm})\end{array}$ \\
\hline $\begin{array}{l}\text { Tanpa mulsa } \\
\text { (Kontrol) }\end{array}$ & 14.32 & 4.17 & $\begin{array}{c}\text { Tidak } \\
\text { terdeteksi }\end{array}$ & $\begin{array}{c}\text { Tidak } \\
\text { terdeteksi }\end{array}$ & $\begin{array}{c}\text { Tidak } \\
\text { terdeteksi }\end{array}$ \\
\hline Arachis pintoi & 13.54 & 9.83 & $\begin{array}{c}\text { Tidak } \\
\text { terdeteksi }\end{array}$ & $\begin{array}{l}\text { Tidak } \\
\text { terdeteksi }\end{array}$ & $\begin{array}{c}\text { Tidak } \\
\text { terdeteksi }\end{array}$ \\
\hline $\begin{array}{l}\text { Mulsa sabut } \\
\text { kelapa }\end{array}$ & 14.04 & 3.86 & $\begin{array}{c}\text { Tidak } \\
\text { terdeteksi }\end{array}$ & $\begin{array}{l}\text { Tidak } \\
\text { terdeteksi }\end{array}$ & $\begin{array}{l}\text { Tidak } \\
\text { terdeteksi }\end{array}$ \\
\hline $\begin{array}{l}\text { Mulsa alang- } \\
\text { alang }\end{array}$ & 13.69 & 5.71 & $\begin{array}{c}\text { Tidak } \\
\text { terdeteksi }\end{array}$ & $\begin{array}{l}\text { Tidak } \\
\text { terdeteksi }\end{array}$ & $\begin{array}{c}\text { Tidak } \\
\text { terdeteksi }\end{array}$ \\
\hline
\end{tabular}

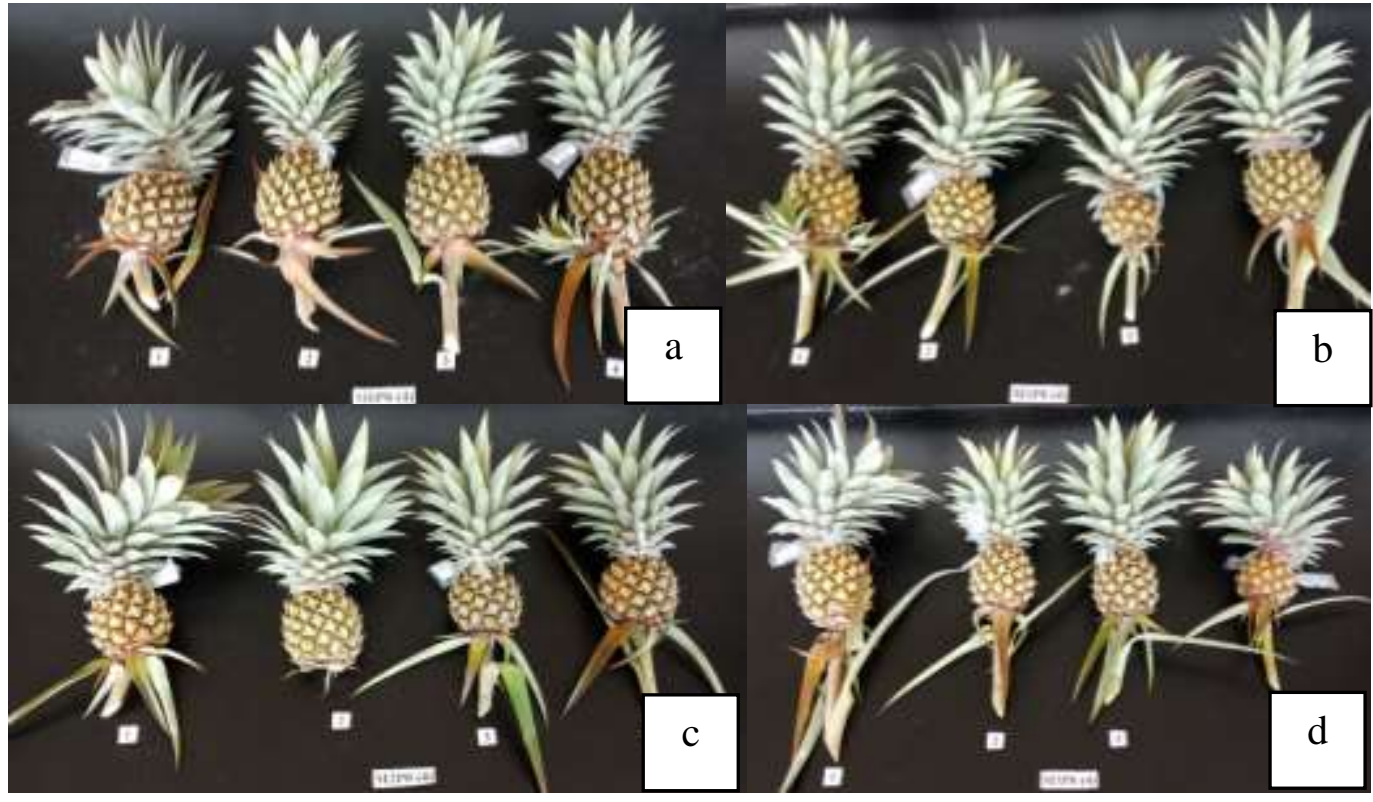

Gambar 2. Keragaan buah nenas menggunakan perlakuan a) tanpa mulsa, b) Arachis pintoi, c) mulsa sabut kelapa, d) mulsa alang-alang 
Hasil uji kandungan vitamin $\mathrm{C}$ pada buah nenas dari perlakuan mulsa Arachis pintoi memiliki nilai yang lebih tinggi dari perlakuan lainnya, menunjukkan tingginya aktivitas biosimetris vitamin $\mathrm{C}$ pada buah dari perlakuan tersebut. Arachis pintoi termasuk kedalam tanaman kacang-kacangan yang dapat menambah nitrogen dalam tanah. Menurut Chozin et al. (2014) Arachis pintoi sebagai tanaman penutup tanah dapat mengikat nitrogen bebas sehingga ketersediaan unsur hara $\mathrm{N}$ untuk tanaman.

Setyawati dan Mustofa (2017) menyatakan bahwa kadar vitamin $\mathrm{C}$ dipengaruhi oleh faktor-faktor yang mempengaruhi fotosintesis. Hal ini disebabkan karena asam askorbat disintesis dari glukosa. Terganggunya fotosintesis atau sintesis glukosa akan mempengaruhi produksi vitamin C oleh tanaman. Zadeh et al. (2007) menyebutkan ada enam enzim yang disandi oleh gen-gen dalam biosintesis vitamin $\mathrm{C}$, diantaranya mio-inositol oksidase (MIO), GDP-Manosa-3',5'-epimerase (GME), Lgalaktono-gamma-lakton dehidrogenase (GLDH), asam D-galakturonic reductase (GaIUA), L-Galaktosa-I-fosfate fosfatase (GalPase), dan L-Galaktosa dehidrogenase $(\mathrm{GalDH})$. Keragaman spesies inilah yang dapat menyebabkan perbedaan kandungan vitamin $C$ pada setiap tumbuhan.

Berdasarkan Gambar 2 dapat dilihat bahwa secara morfologi buah nenas hasil tanaman nenas yang ditanam di lahan pasca tambang timah dengan perlakuan tanpa mulsa, Arachis pintoi, mulsa sabut kelapa dan mulsa alang-alang tidak berbeda. Ukuran buah dan ukuran buah pada semua perlakuan tidak berbeda nyata.

\section{KESIMPULAN}

Aplikasi berbagai jenis mulsa tidak memberikan pengaruh terhadap pertumbuhan dan daya hasil tanaman nenas di lahan pasca tambang timah. Tanaman nenas yang diaplikasikan Arachis pintoi memiliki buah dengan kandungan vitamin $\mathrm{C}$ tertinggi. Buah nenas yang ditanam di lahan pasca tambang timah dengan aplikasi berbagai jenis mulsa tidak mengandung $\mathrm{Pb}, \mathrm{Cu}$, dan $\mathrm{Sn}$.

\section{UCAPAN TERIMA KASIH}

Terima kasih disampaikan kepada Kementerian Riset dan Teknologi yang telah membiayai penelitian ini melalui Hibah Penelitian Terapan tahun 2018-2020 kepada penulis.

\section{DAFTAR PUSTAKA}

[BPS] Badan Pusat Statistik. 2017. Statistik Tanaman Buah-buahan dan Sayuran Tahunan Indonesia 2017. Jakarta: Badan Pusat Statistik.

Antari, R., Wawan, G. M. E. Manurung. 2014. Pengaruh pemberian mulsa organik terhadap sifat fisik dan kimia tanah serta pertumbuhan akar kelapa sawit. JOM. FAPERTA. 1(1): 1-13.

Basuki, J., A. Yunus, E. Purwanto. 2016. Peranan mulsa dalam meningkatkan pertumbuhan dan produksi cabai melalui modifikasi kondisi fisik di dalam tanah. Bul. Part. 2:73-77.

Chozin, M.A., J.G. Kartika, R. Baharudin, 2014. Penggunaan kacang hias (Arachis pintoi) sebagai biomulsa pada budidaya tanaman tomat (Lycopersicon esculentum M.). J. Hort. Indonesia. 4(3):168-174.

Damayanti, D.R.R., N. Aini, Koesriharti. 2013. Kajian penggunaan macam mulsa organik pada pertumbuhan dan hasil tanaman cabai besar (Capsicum annum L.). J. Prod. Tanaman. 1(2): 25-32.

Endang, S.D. 2013. Pengaruh Pemberian mulsa organik terhadap pertumbuhan dan hasil tanaman tomat. J. AgroPet. 10:1-7.

Endriani, J. Barus. 2014. Pengaruh Beberapa Sumber Bahan Organik Lokal terhadap Hasil Kedelai pada Lahan Kering di Lampung. hal. 362-367. Dalam S. Herlinda, Suwandi, F. H. Taqwa, Tanbiyaskur, E. Handayanto, H. M. Sarjan, N. Aini, Rajiman, Mardhiana (eds). Prosiding Seminar Nasional Lahan Suboptimal 2014. Palembang, 26-27 September 2014. 
Ghosh, S. V.L. Prasanna, B. Sowjanya, P. Srivani, M. Alagaraja, D. Banji. 2013. Inductively coupled plasma -optical emission spectroscopy: a review. Asian J. Pharm. Anals. 3(1):24-33

Hamid, I., S.J. Priatna, A. Hermawan. 2017. Karakteristik beberapa sifat fisika dan kimia tanah pada lahan bekas tambang timah. J. Penelitian Sains 19(1):23-31.

Haryadi, D., H. Yetti, S. Yoseva. 2015. Pengaruh pemberian beberapa jenis pupuk terhadap pertumbuhan dan produksi tanaman kailan (Brassica $\begin{array}{llll}\text { alboglabra } & \text { L.). JOM. FAPERTA. }\end{array}$ 2(2):1-10.

Hossain, F., S. Akhtar, M. Anwar. 2015. Nutritional value and medicinal benefits of pineapple. Int. J. of Nutr. and Food Sci. 4(1):84-88.

Jubahar, J., Y. Astuti, N. Suharti. 2015. Penetapan kadar vitamin c dari buah cabe rawit (Capsicum Frutescens L.) dengan metode kromatografi cair kinerja tinggi (KCKT). J. Farmasi Higea. 7: 208-217.

Lestari, T., E.D. Mustikarini, U. Widyastuti, Suharsono. 2011. Analisa Pertumbuhan dan Variasi Somaklonal Beberapa Aksesi Nenas Lokal Bangka Hasil Perbanyakan In Vitro di 4 Lahan Kritis Bangka. hal 941 - 951. Dalam R. Poerwanto, S. Susanto, A. D. Susila, N. Khumaida, D. Sukma, K. Suketi, S. W. Ardhie (eds). Prosiding Seminar Nasional Perhimpunan Hortikultura Indonesia. Lembang, 23-24 November 2011.
Munawir, F.A., M.A. Chozin. 2015. Pemanfaatan residu biomulsa Arachis pintoi dan Legume lainnya pada pola tanam residu jagung-tomat. Agrohorti 3(1) :127-136.

Puspitasari, P., R. Linda, Mukarlina. 2013. Pertumbuhan tanaman pakchoy (Brassica chinensis L.) dengan pemberian kompos alang-alang (Imperata cylindrica (L.) Beauv) pada tanah gambut. J. Proto. 2(2):44-48.

Rahmat, A., Afandi, T. K. B. Manik, P. Cahyono. 2014. Pengaruh Irigasi dan mulsa organik terhadap pertumbuhan tanaman nanas (Ananas comosus) di daerah tropika basah. J. Agro. Trop. 2(1):155-158.

Rumakuway, D., F.J, Rumahlatu, Makaruku. 2016. Pengaruh jenis mulsa organik terhadap pertumbuhan dan produksi tanaman sawi (Brassica juncea L.). J. Budida. Pert. 12(2):74-79.

Setyawati, H., M.A. Mustofa. 2017. Analisis kadar vitamin c kelopak rosella (Hibiscus sabdariffa L.) Muda dan tua yang dikoleksi dari berbagai ketinggian tempat yang berbeda. Biogenesis, J. Ilm. Bio. 5(2):99-103.

Silmi, F., M.A. Chozin. 2014. Pemanfaatan biomulsa kacang hias (Arachis pintoi) pada budidaya jagung manis (Zea mays saccharata Sturt.) di lahan kering. J. Hort. Indo. 5(1):1-9.

Zadeh, H.R., J. Keulemans, M.W. Davey. 2007. Expression Pattern of Key Vitamin C Biosynthesis Genes in Apple. Comm. Appl. Biol. Sci 72 (1): 269-273. 